\title{
Changes in Electrophoretic Pattern of Soluble Proteins of Potato Tuber in Early Period of Infection by Phytophthora infestans
}

\author{
Norio Nishimura*, Kohei Tomiyama** and Noriyuki Doke**

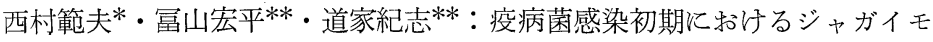 \\ 塊茎組織可溶性蛋白質のグル電気泳動像の変化について
}

Key Words : protein electrophoresis, potato, late blight.

As one of the trials in a series of experiments to elucidate the mechanism of the early response of potato cells to infection by incompatible races of Phytophthora infestans $^{1,2,3,4)}$, gel electrophoresis was carried out on proteins extracted from potato tuber infected by $P$. infestans. Many reports have noted that changes of gel electrophoretic pattern (GEP) were caused by infection with parasites ${ }^{5,6,7,8)}$. However, in most of these experiments, the infected plant tissues were submitted to electrophoretic analysis in a rather late period of infection. In the experiments reported here, we examined the effect of infection by $P$. infestans on GEP of proteins of the potato tuber tissues in an early period of infection.

Tubers of potato cultivar Rishiri ( $\mathrm{R}_{1}$-gene), which is incompatible with race 0 and compatible with race 1 of $P$. infestans were used. Disks, $1 \mathrm{~mm}$ thick and $12 \mathrm{~mm}$ in diameter, were made from the central parenchyma of potato tubers. After rinsing with running water, the disks were incubated in a moist box at $18 \mathrm{C}$ for $12-15 \mathrm{hr}$, and then inoculated with race 0 or race 1 . Twenty-five $\mu l$ of the zoospore suspension was inoculated onto one side of the disks and then again onto the other side $30 \mathrm{~min}$ after the first inoculation. As a control, distilled water was placed on the disks. The zoospore suspension was prepared by the method reported previously ${ }^{1)}$, and the concentration was made to $7 \times 10^{5}$ zoospores $/ \mathrm{ml}$.

The GEP of proteins extracted from tubers stored for more than several months was somewhat different from those of tubers stored for 3 months or less. Aging of the tuber disks also caused some difference in density of the protein bands on GEP. In the present experiments, aged disks of potato tuber stored for more than 8 months were used.

\footnotetext{
* Hokkaido National Agricultural Experiment Station, Hitsujigaoka, Sapporo 061-01, Japan 北海道農業試験場

** Faculty of Agriculture, Nagoya University, Nagoya 464, Japan 名古屋大学農学部

1) Nishimura, N. and Tomiyama, K. (1978). Ann. Phytopath. Soc. Japan 44:159-166. 2) Nishimura, N., Tomiyama, K. and Doke, N. (1978). Ibid. 44:599-605. 3) Nozue, M., Tomiyama, K. and Doke, N. (1979). Physiol. Plant Pathol. 15:111-115. 4) Tomiyama, K., Doke, N., Nozue, M. and Ishiguri, Y. (1978). Recognition and Specificity in Plant Host-Parasite Interaction, Japan Scientific Society Press, Tokyo. pp. 69-84. 5) Ohguchi, T. and Asada, Y. (1975). Physiol. Plant Pathol. 5: 183-192. 6) Tomiyama, K. and Stahmann, M. A. (1964). Plant Physiol. 39: 483-490. 7) Yamamoto, M. and Konno, K. (1976). Plant \& Cell Physiol. 17: 843-846. 8) Yamamoto, H., Hokin, H. and Tani, T. (1978). Phytopath. Z. 91: 193-202.
} 
Microscopic sections were made from the surface of the infected disks 5, 7, 9 and $11 \mathrm{hr}$ after inoculation. The sections were immersed in $0.5 \%$ neutral red solution, and then in $0.8 \mathrm{M}$ sucrose solution, and were observed under a microscope. Cells that were stained with neutral red and could be plasmolyzed, were taken as live cells.

The tuber disks were frozen in a deep freezer $(-20 \mathrm{C})$ at 5,10 and $15 \mathrm{hr}$ after inoculation. Ten frozen disks (about $4 \mathrm{~g}$ ) were ground with sea sand in a mortar with $16 \mathrm{ml}$ of $0.05 \mathrm{M}$ phosphate buffer at $\mathrm{pH} 7.0$ containing $0.1 \%$ mercaptoethanol. The homogenate was centrifuged at $20,000 \times g$ for $30 \mathrm{~min}$, and then the supernatant was again centrifuged at $105,000 \times g$ for $90 \mathrm{~min}$. The supernatant thus obtained was used for the electrophoresis experiments.

After race 0 and race 1 of $P$. infestans were cultured on rye media ${ }^{9)}$ for 2 weeks at $18 \mathrm{C}$, the mycelial mats were washed thoroughly with distilled water. After excess water was eliminated with filter paper, the mycelial mat was ground in a mortar and pestle with liquid $\mathrm{N}_{2}$, and then lyophilized under a vacuum.

Polyacrylamide gel electrophoresis was carried out according to the method of Davis et $a l^{10)}$. Gel column $9 \mathrm{~cm}$ was used. Electrophoresis was conducted at $3 \mathrm{~mA} /$ tube, using tris-glycine buffer at $\mathrm{pH} 8.5$ as a running buffer at $4 \mathrm{C}$. After electrophoresis, the gel removed from the column was stained with Coomassie brilliant blue $\mathrm{R}$ and then destained with $10 \%$ acetic acid containing $50 \%$ methanol. SDS-gel electrophoresis was carried out according to the method of Weber and Osborn ${ }^{11)}$. The densities of protein bands on the stained gel were determined by a densitometer (Jois Co, Ltd).

Time from inoculation by the incompatible race 0 to hypersensitive death of the infected cells of the cultivar Rishiri used in the present experiments was measured. The results showed that 10,50 and $80 \%$ of the infected cells died 5, 8 and $12 \mathrm{hr}$ after inoculation, respectively. In the case of cells infected by the compatible race, no cell death occurred in the present experimental condition.

Little change in GEP was caused by infection with either race 0 or race 1 at $5 \mathrm{hr}$ after inoculation, but changes were recognized at 10 or $15 \mathrm{hr}$ after inoculation. Density of the protein band at $\mathrm{Rf} 0.28$ ( $\mathrm{C}-2$ band) decreased or disappeared by inoculation with race 0 (Fig. 1). A similar tendency was also observed in GEP of the proteins extracted from disks infected by race 1 . A scan of the electropherogram also showed the disappearance of the $\mathrm{C}-2$ band (Fig. 1).

Mycelial powder was added to the non-infected aged disks in a ratio of $1.7,8$ and $17 \mathrm{mg} / \mathrm{g}$. fr. wt ; these were equivalent to 1,5 and $10 \%$ of the dry weight of the tuber disks. The mixtures were homogenized and proteins were extracted by the same method as used in electrophoresis of the infected disks. With the disks to which 5 and $10 \%$ mycelial powder were added, the $\mathrm{C}-2$ protein band decreased or disappeared and the density of the protein at Rf 0.26 (tentatively named $\mathrm{C}-1$ band) increased (Fig. 2). SDS gel electrophoresis of the proteins extracted from the $10 \%$ powder-added disks also showed disappearance of $\mathrm{D}$ band (Fig. 3). It is not certain whether this band is the same as $\mathrm{C}-2$ band. There was no difference between the effects of mycelial powders of the incompatible and compatible races on the protein bands.

9) Caten, C. E. and Jinks, J. L. (1968). Can. J. Bot. 46: 325-348. 10) Davis, B. J. and Ornstein, L. (1964). Ann. New York Acad. Sci. 121:404-427. 11) Weber, K. and Osborn, M. (1968). J. Biol. Chem. 244: 44064412 . 

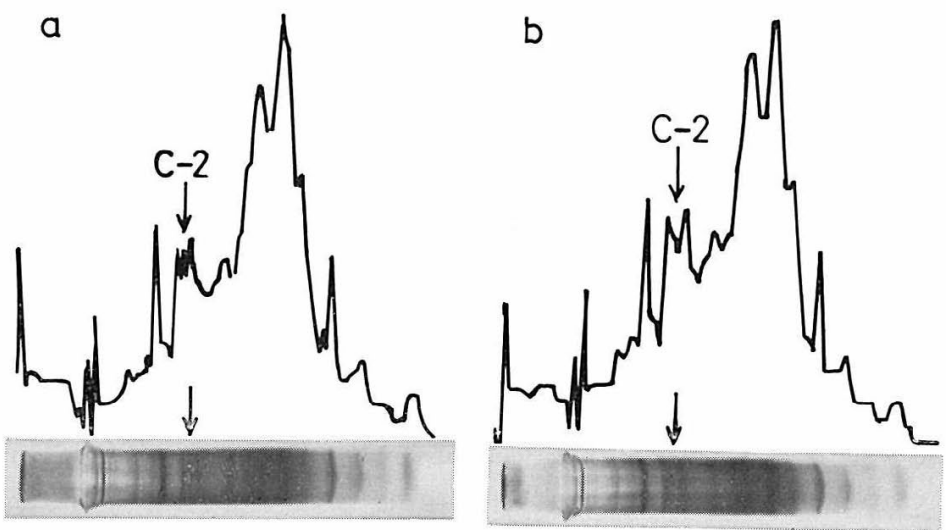

Fig. 1. Polyacrylamide gel electrophoretic pattern of the proteins extracted from potato-tuber disks infected by the incompatible race 0 of $P$. infestans. The proteins were extracted $15 \mathrm{hr}$ after inoculation. a; control, b; infected by race 0 .
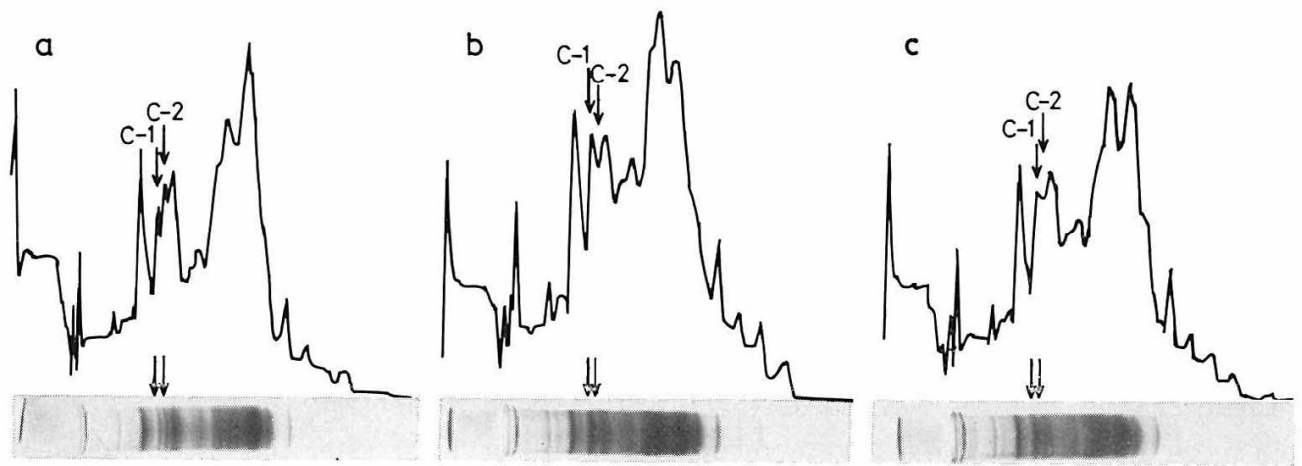

Fig. 2. Polyacrylamide gel electrophoretic pattern of the supernatant fractions of protein extracts obtained by homogenizing the potato-tuber tissue with mycelial powder solution (race 0 and race 1 ). a; no mycelial powder (control), b; mycelial powder of race $0, \mathrm{c}$; mycelial powder of race 1 .
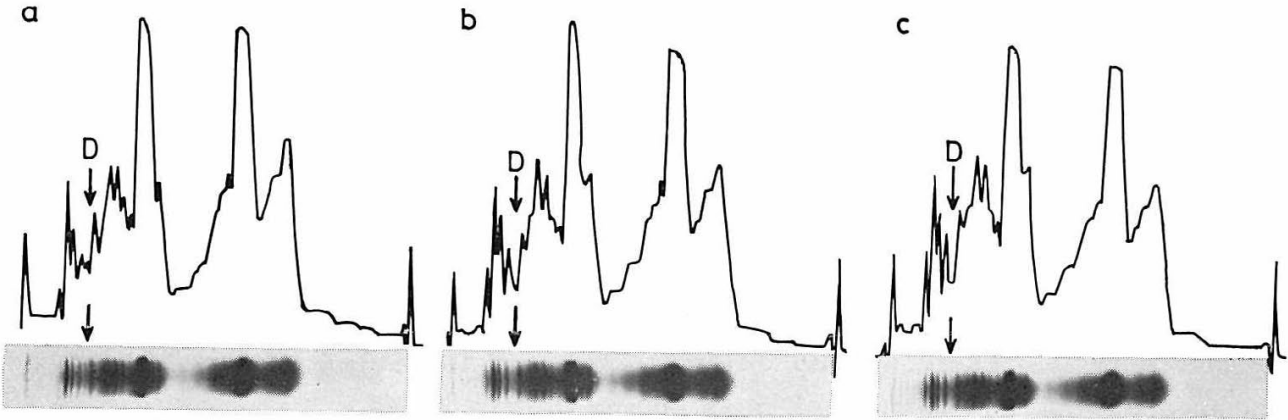

Fig. 3. SDS-polyacrylamide gel electrophoretic pattern of the samples used in the electrophoresis shown in Fig. 2. a; no mycelial powder (control), b: mycelial powder of race $0, c$; mycelial powder of race 1 . 
In the present experimental condition, the only visible difference found in the GEP of proteins between the non-infected tuber disks and those infected by $P$. infestans in early periods of infection was a decrease or disappearance of the $\mathrm{C}-2$ band in the infected disks. However, there seemed to be little difference between the effect of infection by incompatible and compatible races. Proteins extracted by homogenizing the tuber disks in the presence of mycelial powder showed a decrease or disappearance in the $\mathrm{C}-2$ and $\mathrm{D}$ bands and an increase in the $\mathrm{C}-1$ band. One of the most plausible explantion of this phenomenon seemed to be that the disappearance or the decrease in the $\mathrm{C}-2$ band by the infection may be due to binding of the mycelial component to $\mathrm{C}-2$ and possibly $\mathrm{D}$ band proteins. It is uncertain whether the $\mathrm{C}-2$ band protein, which was presumably bound to the mycelial component, was precipitated by centrifugation or moved to the position of $\mathrm{C}-1$ band or some other position.

At a very early time of infection, the infecting hyphae of both compatible and incompatible races were found to be already bound firmly to the host plasma membrane ${ }^{12)}$, There is evidence that potato lectin may play an important role in this binding ${ }^{12,13)}$. The $\mathrm{C}-2$ and $\mathrm{D}$ protein bands could possibly relate to the binding phenomena, although there is so far no experimental evidence for this. Further investigation is necessary to determine the physiological significance of the $\mathrm{C}-1$ protein band.

At the time of protein extraction, some of or almost all of the cells of potato tuber infected by the incompatible race have already died. The death of the infected cells did not seem to cause apparent difference in GEP in the present condition of analytical method, as the GEP of the compatible race-infected tissue, whose cells did not die, was the same as that of the incompatible race-infected tissue.

(Received July 27, 1981)

12) Nozue, M., Tomiyama, K. and Doke, N. (1980). Physiol. Plant Pathol. 17: 221-227. 13) Furuichi, N., Tomiyama, K. and Doke, N. (1980). Ibid. 16:249-256. 